\title{
The Nucleic Acid Contents of Viruses
}

\author{
By A. C. ALLISON and D. C. BURKE \\ National Institute for Medical Research, London, N.W.7
}

(Received 28 February 1961)

\section{SUMMARY}

The nucleic acid contents of purified suspensions of mouse pneumonitis organisms (Nigg), pox viruses, adenovirus type 5, the iridescent virus of Tipula and avian myeloblastosis virus were analysed. From these results and published information the absolute amounts of nucleic acid in each virus particle were calculated and are presented in tabular form. Some generalizations can be made about the nucleic acid composition of different groups of organisms reproduced in cells; these are discussed in relation to the possible evolutionary origins of the organisms.

\section{INTRODUCTION}

Knight (1954) pointed out that although plant viruses differ considerably in size they all have nearly the same absolute content of ribonucleic acid (RNA). FrischNiggemeycr (1956) calculated that the same amount of RNA, representing a molecular weight of about 2 millions, is also present in animal viruses (influenza, fowl plague, equine encephalitis and poliomyelitis). In the present paper it will be shown that the generalization about the absolute nucleic acid content can be extended to include the cytoplasmic RNA viruses of insects. The absolute nucleic acid contents of other viruses and organisms multiplying within cells have been calculated from published information and the results of our own analyses of several preparations.

From this compilation some other generalizations emerge. In the first place, organisms belonging to the rickettsia and psittacosis-lymphogranuloma groups contain both deoxyribonucleic acid (DNA) and RNA, even in highly purified preparations. Both kinds of nucleic acid seem to be essential constituents of these organisms; loss of RNA is associated with a decrease in infectivity. This fact, together with several others discussed below, suggests that organisms in the rickettsia and psittacosis-lymphogranuloma groups have closer affinities with bacteria than with any of the true viruses, the genetic apparatus of which probably consists of either DNA or RNA, but not both (Lwoff, 1957). Secondly, it seems that the absolute nucleic acid contents of most DNA viruses, whether they infect bacteria, insect or vertebrate cells, fall within a relatively limited range, corresponding to molecular weights of $60-150$ millions --that is, from 30 to 75 times as much nucleic acid as in the RNA viruses. Two groups of viruses are exceptional in having much lower DNA contents. These are the small, spherical bacteriophages, one member of which is known to have a single-stranded DNA, and certain mammalian tumour viruses. Our own observations were made in an attempt to fill in some of the more 
important gaps in available information on the nucleic acid contents of viruses and other organisms reproduced within cells. In the discussion these results are tabulated along with published information on other viruses.

\section{METHODS}

Highly concentrated and purified suspensions of mouse pneumonitis organisms, pox viruses, adenovirus type 5, the iridescent virus of Tipula and avian myeloblastosis virus were analysed by the diphenylamine technique of Burton (1956) for DNA and the method of Webb (1956) for RNA. Protein was determined by the technique of Lowry, Rosebrough, Farr \& Randall (1951), with bovine albumin as a standard. Methods of preparation of suspensions are described along with results.

In most of the preparations analysed, electron microscopic spray counts of particles were made by Dr R. C. Valentine as described by Williams \& Backus (1949). Counts of larger organisms were made in smears delivered from loops of known volume (Hart \& Rees, 1960) calibrated with ${ }^{131}$ I-labelled albumin, and stained by the acridine orange technique (Armstrong \& Niven, 1957). In the discussion, where particle counts were not available, absolute nucleic acid contents were calculated from the $\%$ nucleic acid, the size and the density of the particles. The results are expressed as molecular weights of nucleic acid per particle, since this figure allows a direct comparison between different viruses and provides an estimate of the amount in each one.

Assessment of the purity of virus suspensions is always difficult. We took as criteria of purity: (1) absence of significant contamination visible on electron microscopy and acridine orange staining; (2) comparison of the amount of nucleic acid recovered in the suspension with that expected of the corresponding number of virus particles, their size, density and \% nucleic acid being known. In the case of vaccinia virus an additional check on the purification procedure was used. To crude unlabelled virus preparations homogenates of cells labelled with ${ }^{32} \mathrm{P}$ were added. The radioactivity of the purified virus preparation could be taken as a measure of host cell contamination, and proved to be less than $20 \%$.

\section{RESULTS}

Mouse pneumonitis organism (Nigg). The Hampstead strain of this organism was grown in mouse embryo cell cultures prepared as described by Allison \& Armstrong (1960). Cells were homogenized in a Potter-type apparatus and the material submitted to differential centrifugation followed by chromatography on modified cellulose columns (Hoyer et al. 1958). The suspensions of organisms obtained showed, when stained with acridine orange, the bright yellow-green fluorescence characteristic of DNA. Both DNA and RNA were found on analysis (Table 2). The value for RNA may be low because of loss during preparation.

Pox viruses. The Lister Institute rabbit-adapted strain of vaccinia virus (Amies, 1938), in its 81st passage in rabbit skin, was used. The cowpox virus was also a Lister Institute strain, distinguishable from vaccinia virus in that only cowpox gave haemorrhagic lesions on the chorioallantoic membrane of chick embryo. Material grown in rabbit skin was purified by three cycles of extraction with trifluorotrichloroethane (Arcton 113) (Gessler, Bender \& Parkinson, 1956), differential centrifugation and repeated flocculation with $\mathbf{M}$-sodium chloride 
(Dawson \& McFarlane, 1948). Virus was dispersed in distilled water by brief exposure to ultrasonic vibrations from a magnetostriction transducer.

Electron micrographic spray counts of the final preparations gave particle counts of the order of 2 to $3 \times 10^{11} / \mathrm{ml}$. All preparations gave concentrations of DNA of 2.46 to $2.92 \times 10^{-16} \mathrm{~g}$./particle. Two preparations of vaccinia virus and one of cowpox virus contained small but definitely detectable amounts of RNA. This RNA was probably due to residual contamination with host material, since after further salt flocculation and dispersion only a trace of colour was given by the $p$-bromophenylhydrazine reagent. If the colour was due to RNA, then the amount of RNA was less than one-thirtieth of the amount of DNA in the preparations. However, the absorption maximum at $450 \mathrm{~m} \mu$ characteristic of $p$-bromophenylhydrazone (Webb, 1956) was absent, suggesting that the trace of colour was probably due to some non-specific reaction, possibly with carbohydrate. We therefore conclude that pox virus particles contain about $2.6 \times 10^{-16} \mathrm{~g}$. DNA/particle and no RNA. The particles showed bright yellow-green fluorescence when stained with acridine orange.

Adenovirus. Three highly concentrated preparations of adenovirus type 5, grown in HeLa cells and prepared as described by Pereira \& Valentine (1958), were available for study. Centrifugation in a caesium chloride density gradient (carried out in collaboration with Dr H. G. Pereira) showed that the particles had a density of 1.34. All three preparations showed the presence of DNA in amounts estimated at 1.2 to $2.3 \times 10^{-16} \mathrm{~g}$./particle. Two of the preparations showed traces of RNA, the third no detectable RNA. The latter also had the lowest DNA content, and was thought to be without significant host cell contamination. It is therefore tentatively concluded that adenovirus type 5 has about $1.2 \times 10^{-16} \mathrm{~g}$. DNA/particle, the nucleic acid content being about $30 \%$; and no RNA. This result is consistent with the density of the particle.

The iridescent virus of Tipula. A suspension of this virus was purified by Arcton extraction and differential centrifugation. Electron micrographic spray counts showed the presence of $2.7 \times 10^{11}$ particles $/ \mathrm{ml}$. The amount of DNA recovered corresponded to $2.3 \times 10^{-16} \mathrm{~g}$./particle, representing a nucleic content of $16 \%$; no RNA was detectable.

Avian myeloblastosis virus. This virus was prepared and purified as described by Bonar \& Beard (1959). The RNA content of the virus was $1 \%$, with good agreement in duplicates; no DNA was detected.

\section{DISCUSSION}

Information about the absolute nucleic acid contents of viruses and other organisms reproduced intracellularly is summarized in Tables 1-4. In Table 1, two organisms, Escherichia coli and Mycoplasma gallisepticum, both of which multiply in the absence of cells, are included for comparison. Certain generalizations about the nucleic acid contents of these organisms can now be made with some confidence.

\section{Rickettsias}

Smith \& Stoker (1951) reported that Rickettsia burneti grown in yolk sacs of chick embryos contained $9.7 \%$ (dry weight) of DNA and $4.3 \%$ of RNA (Table 2). Different preparations were found to have the same \% DNA but variable concentrations of RNA, which was nevertheless consistently present. The purine and pyrimidine 
Table 1. DNA and RNA contents of various organisms

\begin{tabular}{|c|c|c|c|c|c|c|c|}
\hline Group & Organism & Shape & $\begin{array}{l}\text { Dimensions } \\
\qquad(\mathrm{m} \mu)\end{array}$ & $\begin{array}{c}\text { DNA } \\
\%\end{array}$ & $\begin{array}{c}\text { DNA } \\
\text { mol. wt. } \\
\left(\times 10^{-6}\right)\end{array}$ & $\underset{\%}{\text { RNA }}$ & $\begin{array}{c}\text { RNA } \\
\text { mol. wt. } \\
\left(\times 10^{-6}\right)\end{array}$ \\
\hline $\begin{array}{l}\text { Gram-negative } \\
\text { bacteria }\end{array}$ & $\begin{array}{l}\text { Escherichia } \\
\text { coli }\end{array}$ & Rod & $3000 \times 1000$ & $4 \cdot 4(1)$ & 25,000 & $22 \cdot 6$ & 130,000 \\
\hline $\begin{array}{l}\text { Pleuropneumonia- } \\
\text { like organism }\end{array}$ & $\begin{array}{l}\text { Mycoplasma } \\
\text { gallisepticum }\end{array}$ & Spherical & 250 diameter & $6(2)$ & 75 & $?$ & $?$ \\
\hline Rickettsia & $\begin{array}{l}\text { R. burneti } \\
\text { R. mooseri }\end{array}$ & $\begin{array}{l}\text { Rod } \\
\text { Rod }\end{array}$ & $\begin{array}{l}600 \times 250 \\
600 \times 300\end{array}$ & $\begin{array}{l}9 \cdot 7(3,4) \\
0 \cdot 9(5,6)\end{array}$ & $\begin{array}{r}1680 \\
224\end{array}$ & $\begin{array}{l}4 \cdot 3 \\
3 \cdot 0\end{array}$ & $\begin{array}{l}749 \\
747\end{array}$ \\
\hline \multirow[t]{3}{*}{$\begin{array}{l}\text { Psittacosis- } \\
\text { lymphogranuloma }\end{array}$} & $\begin{array}{l}\text { Meningo- } \\
\text { pneumonitis }\end{array}$ & Spherical & 270 diameter & $5-10(7)$ & 1200 & $0(?)$ & $0(?)$ \\
\hline & $\begin{array}{l}\text { Feline } \\
\text { pneumonitis }\end{array}$ & Spherical & 270 diameter & $6(8)$ & 1400 & 16 & 3740 \\
\hline & $\begin{array}{l}\text { Mouse } \\
\text { pneumonitis }\end{array}$ & Spherical & 270 diameter & $6.5(P)$ & 1520 & 4.7 & 1180 \\
\hline
\end{tabular}

References are given in parentheses. $P$-personal observations (see text). (1) Roberts et al. (1955); (2) Morawitz \& Cleverden (1959); (3) Smith \& Stoker (1951); (4) Cohen \& Chargaff (1944); (5) Wyatt \& Cohen (1952); (6) Cohn et al. (1958); (7) Crocker (1952); (8) Ross \& Gogolak (1957).

base composition of the rickettsial DNA was found to be similar to that of chick embryo, except that chick embryo contained 5-methylcytosine. To account for the similarity in base composition, the authors mention the possibility that rickettsias may incorporate nucleic acid directly from the host. However, Wyatt \& Cohen (1952) found a very different base composition in the DNA of Rickettsia prowazeki grown in chick embryo (Table 2). This large difference between the two organisms, if substantiated, resembles the considerable differences in DNA base ratios among bacteria, to which attention has been drawn (Belozersky \& Spirin, 1958; Marmur \& Doty, 1958) and which raises some interesting problems in connexion with the coding of genetic information. In both rickettsias the adenine:thymine and guanine: cytosine ratios were close to unity, which suggests strongly that the DNA exists in the double-stranded helical form with base-pairing as described by Watson \& Crick (1953).

Table 2. DNA bases in rickettsias (\% proportional)

\begin{tabular}{lccccc}
\multicolumn{1}{c}{ Organism } & Adenine & Thymine & Guanine & Cytosine & Reference \\
R. burneti & $\mathbf{2 9 \cdot 5}$ & $\mathbf{2 6 \cdot 0}$ & $\mathbf{2 2 \cdot 5}$ & $\mathbf{2 2 \cdot 0}$ & $(\mathbf{1})$ \\
R. prowazeki & $\mathbf{3 5 . 7}$ & $\mathbf{3 1 \cdot 8}$ & $\mathbf{1 7 \cdot 1}$ & $\mathbf{1 5 \cdot 4}$ & (2)
\end{tabular}

(1) Smith \& Stoker (1951); (2) Wyatt \& Cohen (1952).

Cohn, Hahn, Cegalowski \& Bozeman (1958) reported that both DNA and RNA were present in purified Rickettsia mooseri. Assuming a nitrogen content of $13 \%$ (Smith \& Stoker, 1951; Cohen \& Chargaff, 1944), their figures correspond to $0.8 \%$ DNA and $2.9 \%$ RNA. This figure for DNA is considerably less than that given for R. burneti by Smith \& Stoker, and it remains to be seen whether the discrepancy is genuine. Cohn et al. (1958) found that on incubation of suspensions of $R$. mooseri at $36^{\circ}$ RNA was liberated into the medium. There was a concomitant decrease in the infectivity of the preparations which was not prevented by nucleotide supplements. Lability of RNA could account also for the low and variable recoveries of RNA in $R$. burneti by Smith \& Stoker. 


\section{Psittacosis-lymphogranuloma group}

Histochemical studies suggested that the feline pneumonitis organism contains both DNA and RNA (Moulder \& Weiss, 1951). The first physicochemical analysis of purified meningopneumonitis organisms, however, gave particle weights of 2.5 to $5 \times 10^{-14} \mathrm{~g}$. with 5-10\% DNA and no demonstrable RNA (Crocker, 1952). In calculating the absolute amounts of nucleic acid in organisms belonging to this group, we have assumed that they are spherical, with diameters of $270 \mathrm{~m} \mu$, as found in freeze-dried preparations (Crocker \& Williams, 1955). Much greater diameters are observed in air-dried specimens examined by electron microscopy.

Zahler \& Moulder (1953) reported that purified feline pneumonitis organisms have both DNA and RNA. From the given values of DNA- and RNA-phosphorus and total nitrogen/LD $\mathrm{L}_{50}$ dose, it can be calculated that the organisms had approximately $6 \%$ DNA and $16 \%$ RNA. Ross \& Gogolak (1957) reported results of nucleic acid base analyses of purified psittacosis and feline pneumonitis organisms which indicated the presence in both of DNA and RNA. Our results show that the mouse pneumonitis organism also has both RNA and DNA. Although only DNA fluorescence is visible when suspensions of particles are examined after acridine orange staining, substantial amounts of RNA are apparent when the organisms are developing in mouse embryo cells, as shown by Pollard, Starr, Moore \& Tanami (1960) for psittacosis grown in human amnion cells.

In general, it appears to be established that all organisms in the rickettsia and psittacosis-lymphogranuloma groups contain both DNA and RNA. The variable recoveries of RNA, and the fact that in one analysis of the meningopneumonitis organism RNA was not found, are probably due to the relative lability of RNA, which can diffuse out of the particles easily, whereas DNA is more firmly bound. Loss of RNA may well be one of the factors responsible for the loss of infectivity of these organisms on incubation at $36^{\circ}$, even in the presence of nucleotide supplements.

In addition to the consistent presence of both nucleic acids in these organisms, several findings imply closer relationship with bacteria than with the true viruses. Rickettsias undergo binary fission (Schaechter, Bozeman \& Smadel, 195\%). The sensitivity of members of the rickettsia and psittacosis-lymphogranuloma groups to sulphonamides and tetracyclines, and the failure of any true viruses to be affected by these drugs, have been known for some time (Werner, 1958). Recently, it has been shown that rickettsias and members of the psittacosis-lymphogranuloma groups have cell walls similar to those of bacteria, consisting of mucopeptides containing muramic acid and digested by lysozyme (Allison \& Perkins, 1960). The sensitivity of these organisms to penicillin in relatively high dosage may be due to inhibition of cell-wall synthesis; this is the main effect of penicillin so far known in bacteria (Park, 1958; Rogers \& Perkins, 1959). Pox viruses and myxoviruses do not possess cell walls of this kind, and penicillin even in very high doses is without effect on virus growth.

All these findings suggest that organisms of the rickettsia and psittacosislymphogranuloma groups are probably bacteria which have become adapted to intracellular multiplication. Perhaps they have lost the capacity to synthesize certain enzymes necessary for growth and replication, and so have become obligate 
intracellular parasites. In the rickettsias of insects there seems to be no sharp line of distinction between intracellular and free-living forms (Steinhaus, 1946). Moreover, typical bacteria are known (e.g. Mycobacterium lepraemurium) which multiply only within animal cells.

Organisms of the rickettsia and psittacosis-lymphogranuloma groups have somewhat more DNA than the large DNA viruses or Mycoplasma gallisepticum, which is a free-living pleuropneumonia-like organism (Morawitz \& Cleverden, 1959).

\section{RNA viruses}

As previously pointed out (Knight, 1954; Frisch-Niggemeyer, 1956; Schäfer, 1959), the RNA contents of plant and animal viruses for which published figures are available are of the same order, representing molecular weights of about 2 millions. The data listed in Table 3 show that this generalization can be extended to include the only two insect cytoplasmic viruses so far analysed, so far as we are aware.

\section{Table 3. Nucleic acid contents of RNA viruses}

\begin{tabular}{|c|c|c|c|c|c|c|}
\hline Group & Virus & Shape & $\begin{array}{l}\text { Dimensions } \\
\text { or } \\
\text { diameter } \\
(\mathrm{m} \mu)\end{array}$ & $\begin{array}{c}\text { RNA } \\
\%\end{array}$ & $\begin{array}{l}\text { RNA } \\
\text { mol. wt. } \\
\left(\times 10^{-6}\right)\end{array}$ & References \\
\hline $\begin{array}{l}\text { Rod-like } \\
\text { plant } \\
\text { viruses }\end{array}$ & $\begin{array}{l}\text { Tobacco mosaic } \\
\text { Tobacco rattle } \\
\text { Potato } \mathrm{X}\end{array}$ & $\begin{array}{l}\text { Rod } \\
\text { Rod } \\
\text { Rod }\end{array}$ & $\begin{array}{l}300 \times 15 \\
180 \times 25 \\
600 \times 10\end{array}$ & $\begin{array}{l}5 \cdot 7 \\
5 \cdot 0 \\
5 \cdot 7\end{array}$ & $\begin{array}{l}2 \cdot 2 \\
2 \cdot 7 \\
2 \cdot 6\end{array}$ & $\begin{array}{l}(1,2) \\
(2, \mathbf{3}) \\
(2)\end{array}$ \\
\hline $\begin{array}{l}\text { Spherical } \\
\text { plant } \\
\text { viruses }\end{array}$ & $\begin{array}{l}\text { Turnip yellow mosaic } \\
\text { Southern bean mosaic } \\
\text { Tomato bushy stunt } \\
\text { Tobacco necrosis }\end{array}$ & $\begin{array}{l}\text { Sphere } \\
\text { Sphere } \\
\text { Sphere } \\
\text { Sphere }\end{array}$ & $\begin{array}{l}22 \\
25 \\
30 \\
23\end{array}$ & $\begin{array}{l}35 \\
20 \\
17 \\
18\end{array}$ & $\begin{array}{l}2 \cdot 0 \\
1 \cdot 9 \\
2 \cdot 1 \\
1 \cdot 5\end{array}$ & $\begin{array}{l}(2,4) \\
(2,5) \\
(2,6) \\
(2,7)\end{array}$ \\
\hline $\begin{array}{l}\text { Spherical } \\
\text { vertebrate } \\
\text { virus }\end{array}$ & $\begin{array}{l}\text { Poliomyelitis } \\
\text { Foot and mouth } \\
\text { Encephalomyocarditis }\end{array}$ & $\begin{array}{l}\text { Sphere } \\
\text { Sphere } \\
\text { Sphere }\end{array}$ & $\begin{array}{l}27 \\
25 \\
27\end{array}$ & $\begin{array}{l}25 \\
40 \\
30\end{array}$ & $\begin{array}{l}1 \cdot 75 \\
3 \cdot 1 \\
2 \cdot 10\end{array}$ & $\begin{array}{l}(8) \\
(9,10) \\
(11)\end{array}$ \\
\hline Arborvirus & Equine encephalitis & Sphere & 50 & $4 \cdot 4$ & $\mathbf{2 \cdot 2}$ & (8) \\
\hline Myxovirus & $\begin{array}{l}\text { Influenza } \\
\text { Fowl plague }\end{array}$ & $\begin{array}{l}\text { Sphere } \\
\text { Sphere }\end{array}$ & $\begin{array}{l}80 \\
70\end{array}$ & $\begin{array}{l}0 \cdot 8 \\
1 \cdot 8\end{array}$ & $\begin{array}{l}2 \cdot 3 \\
2 \cdot 7\end{array}$ & $\begin{array}{l}(8) \\
(8)\end{array}$ \\
\hline $\begin{array}{l}\text { Avian } \\
\text { tumour }\end{array}$ & Myeloblastosis & Sphere & $80-110$ & $\mathbf{2} \cdot \mathbf{3}$ & $4 \cdot 9$ & Present study \\
\hline \multirow[t]{2}{*}{$\begin{array}{l}\text { Insect } \\
\text { cytoplasmic }\end{array}$} & From Dasychira pudibunda & Sphere & 40 & 7 & $2 \cdot 5$ & $(12,13)$ \\
\hline & From Sphinx populi & Sphere & 80 & $0 \cdot 9$ & $\mathbf{2 \cdot 6}$ & (12) \\
\hline
\end{tabular}

(1) Hopkins \& Sinsheimer (1959); (2) Paul (1059); (3) Harrison \& Nixon (1959); (4) Markham \& Smith (1951); (5) Miller \& Price (1946); (6) de Fremery \& Knight (1955); (7) Bawden \& Pirie (1945); (8) Schäfer (1959);

(9) Ströhmaier \& Mussgay (1959); (10) Bradish et al. (1960); (11) Faulkner et al. (1960); (12) Bergold (1958);

(13) Krieg (1956).

Certain points deserve comment. The figure for the total amount of nucleic acid in foot-and-mouth disease virus is based on sedimentation analysis of extracted RNA (Ströhmaier \& Mussgay, 1959). If this figure and the recent observations suggesting particle diameters of 24-25 $\mathrm{m} \mu$ (Bradish, Henderson \& Kirkham, 1960) are correct, then the virus has an unusually high \% RNA. The RNA content of tobacco rattle virus given in Table 3 is based on the large particle size observed (Harrison \& Nixon, 1959) since the smaller particles are not infective, although they have the same density as the larger particles. There is some uncertainty about the dimensions 
of tobacco necrosis virus, and the rather low figure for total RNA calculated for this virus may have to be revised.

The figure given for the avian myeloblastosis virus is based on our own analysis, which gave similar proportions of RNA in the virus to the published figure of $\mathbf{2 . 2} \%$ (Bonar \& Beard, 1959).

\section{$D N A$ viruses}

Bacteriophages. The DNA contents of several bacteriophages have been published. The T 2, T4 and T6 coliphages have about the same size and phosphorus content, representing a total DNA content of about $2 \times 10^{-16} \mathrm{~g}$. and a molecular weight of DNA of about 120 millions/organism (Table 4). The smaller T1, T3, T5 and T7 coliphages have somewhat lower phosphorus contents, which are of the same order in all. Taking Lunan \& Sinsheimer's (1956) figure for Tr as representative, $61 \%$ of the total $P$ is present in DNA, and each particle has $5.8 \times 10^{-17} \mathrm{~g}$. DNA, giving a molecular weight of 35 millions. Phosphorus analyses suggest that the DNA contents of Salmonella P22 and Pyocyanea P2 and P8 temperate phages are

Table 4. Nucleic acid contents of DNA viruses

\begin{tabular}{|c|c|c|c|c|c|c|}
\hline Group & Virus & Shape & $\begin{array}{l}\text { Dimensions } \\
\qquad(\mathrm{m} \mu)\end{array}$ & $\begin{array}{c}\text { DNA } \\
\%\end{array}$ & $\begin{array}{l}\text { DNA } \\
\text { mol. wt. } \\
\times 10^{-6}\end{array}$ & References \\
\hline $\begin{array}{l}\text { Large } \\
\text { bacterio- } \\
\text { phage }\end{array}$ & $\begin{array}{l}\text { T2, T4, T6 } \\
\text { T1, T3, T7 } \\
\text { Salmonella P22 } \\
\text { Pyocyanea P2, } 8\end{array}$ & $\begin{array}{l}\text { Prismatic } \\
+ \text { tail } \\
?\end{array}$ & $\left\{\begin{array}{l}95 \times 65 \text { (head) } \\
50 \times 45 \text { (head) } \\
45 \times 45 \text { (head) } \\
50 \times 45 \text { (head) } \\
?\end{array}\right.$ & $\begin{array}{r}40 \\
40 \\
45 \\
40 \\
?\end{array}$ & $\begin{array}{r}120 \\
35 \\
60 \\
35 \\
50\end{array}$ & $\begin{array}{l}(1,2) \\
(3,4) \\
(4) \\
(4) \\
(4)\end{array}$ \\
\hline $\begin{array}{l}\text { Small } \\
\text { bacterio- } \\
\text { phage }\end{array}$ & X174 & Spherical & 37 diameter & 25 & $1 \cdot 7$ & (5) \\
\hline $\begin{array}{l}\text { Insect } \\
\text { nuclear }\end{array}$ & $\begin{array}{l}\text { From Bombyx mori } \\
\text { From Lymantria dispar } \\
\text { From Aporia crataegi }\end{array}$ & Rod & $\left\{\begin{array}{l}279 \times 40 \\
300 \times 30 \\
220 \times 50\end{array}\right.$ & $\begin{array}{r}13 \\
16 \\
9\end{array}$ & $\begin{array}{l}76 \\
56 \\
58\end{array}$ & $\begin{array}{l}(6) \\
(7) \\
(8)\end{array}$ \\
\hline $\begin{array}{l}\text { Insect } \\
\text { cytoplasmic }\end{array}$ & Tipula iridescent & Icosahedral & 130 diameter & 16 & 156 & Present study \\
\hline Pox virus & $\begin{array}{l}\text { Vaccinia } \\
\text { Cowpox }\end{array}$ & Brick & $260 \times 220 \times 220$ & $\left\{\begin{array}{l}7 \cdot 8 \\
7 \cdot 2\end{array}\right.$ & $\begin{array}{l}156 \\
156\end{array}$ & $\begin{array}{l}\text { Present study } \\
\text { Present study }\end{array}$ \\
\hline $\begin{array}{l}\text { Adenovirus } \\
\text { Animal } \\
\text { tumour }\end{array}$ & $\begin{array}{l}\text { Adenovirus type } \\
\text { Rabbit papilloma }\end{array}$ & Icosahedral & $\left\{\begin{array}{l}70 \text { diameter } \\
45 \text { diameter }\end{array}\right.$ & $\begin{array}{r}30 \\
8\end{array}$ & $\begin{array}{r}66 \\
7\end{array}$ & $\begin{array}{l}\text { Present study } \\
\text { (9) }\end{array}$ \\
\hline
\end{tabular}

(1) Cohen (1957); (2) Stent \& Fuerst (1955); (3) Lunan \& Sinsheimer (1956); (4) Stent (1958); (5) Sinsheimer (1959); (6) Bergold (1947); (7) Smith \& Wyatt (1951); (8) Bergold (1958); (9) Watson \& Littlefield (1960).

slightly greater than that of Tr (Stent, 1958), and DNA contents have been calculated on the assumption that in these phages also $61 \%$ of the phosphorus is in DNA. In contrast to these results, Sinsheimer (1959) found that the small phage $\phi \mathrm{X} 174$ had a very low DNA content, corresponding to a molecular weight of 1.7 millions. The DNA extracted from these organisms had the same molecular weight, from which it seems that all the DNA in the phage particle is present in a single molecule. Evidence was presented that the polynucleotide chain was single stranded, in 
contrast to the usual double-stranded form. Interest has been aroused by the recent description by Loeb \& Zinder (1961) of an RNA-containing bacteriophage.

Pox viruses. Very little has been published on the DNA content of mammalian viruses. Smadel, Rivers \& Pickels (1939) estimated the dry weight of the vaccinia virus particle to be $5 \cdot 34 \times 10^{-15} \mathrm{~g}$. The volume of a brick-shaped particle with dimensions $260 \times 220 \times 220 \mathrm{~m} \mu$ is $1.25 \times 10^{-14} \mathrm{~cm} .^{3}$, and the dry weight would be about $3.6 \times 10^{-15} \mathrm{~g}$., in fairly good agreement with the value of Smadel et al. The DNA content of purified vaccinia virus was given by Hoagland, Lavin, Smadel \& Rivers (1940) as 5.6\%, from which the amount of DNA/particle can be computed as $2.0 \times 10^{-16} \mathrm{~g}$. As far as we are aware, it has never been established previously whether pox viruses contain significant amounts of RNA. The analyses of Hoagland et al. (1940) were not decisive, since they were based on nucleic acid isolated with the use of hot aqueous sodium hydroxide, which would have eliminated by hydrolysis any RNA present. The problem is of interest since the presence of two different nucleic acids in an organism might be taken as a criterion for rejecting it as a true virus; the pox viruses are the largest of the true viruses on this definition, as our results show. We have concluded that pox virus particles have about $2 \cdot 6 \times 10^{-16} \mathrm{~g}$. DNA and no RNA.

Adenovirus. There is general agreement that adenoviruses contain DNA. Morgan, Howe, Rose \& Moore (1956), who examined adjacent thin and ultrathin sections of cells infected with adenovirus type 3 by histochemical techniques and electron microscopy, showed that parts of the nucleus packed with virus particles were Feulgen-positive. Armstrong \& Hopper (1959) found that adenovirus-infected cells stained with acridine orange had accumulations of large amounts of DNA-containing material in nuclei; similar histochemical results were obtained with partially purified adenovirus suspensions by Epstein, Holt \& Powell (1960). Valentine (1959) concluded from electron scattering of adenovirus type 5 particles stained with uranyl acetate that the nucleic acid content of the particles was high, perhaps as high as $50 \%$. Our results confirm that adenovirus type 5 contains DNA and no RNA, the nucleic acid content of the particles being of the order of $30 \%$.

Papilloma virus. Taylor, Beard, Sharp \& Beard (1942) reported that the Shope papilloma virus had $9 \%$ DNA. Subsequent electron micrographs have shown that this virus is spherical, with a diameter of about $45 \mathrm{~m} \mu$ (Williams, Kass \& Knight, 1960). The calculated DNA molecular weight is thus about 7 millions. Recently Watson \& Littlefield (1960) found the papilloma virus to have $8 \%$ DNA. Isolated DNA proved to be double-stranded and to have two components (21 S and 28S) on ultracentrifugation (7 and 14 million). The larger component seems too large for a virus particle of molecular weight 45 million and $8 \%$ DNA. Hence it is either an artefact (perhaps a dimer) or most particles in the preparations examined were incomplete, with low DNA contents.

Tipula iridescent virus. This virus multiplies in the cytoplasm of susceptible insect cells. It is icosahedral, with a diameter of $130 \mathrm{~m} \mu$ and contains DNA (Williams \& Smith, 1957). Histochemical studies have shown considerable accumulations of DNA-containing material in the cytoplasm of cells infected with the virus (Armstrong \& Niven, 1957). The amount of DNA recovered in our preparations corresponded to $2 \cdot 3 \times 10^{-16} \mathrm{~g}$ /particle, representing $16 \%$ of the dry weight; no RNA was present. 
Nuclear polyhedral viruses of insects. The nuclear polyhedral viruses of insects so far analysed contain DNA and no RNA. From the sizes and percentages of DNA given in Table 4 it can be calculated that the absolute contents are of the order of $10^{-16} \mathrm{~g} \cdot /$ particle.

\section{Comment on $D N A$ viruses}

Table 4 shows that in a large number of DNA viruses (10 bacteriophages, 3 nuclear and one cytoplasmic insect virus, and 3 mammalian viruses) the absolute amount of nucleic acid/particle does not have a wide distribution but falls within the relatively narrow range of $0 \cdot 6$ to $2 \cdot 6 \times 10^{-16} \mathrm{~g}$. It would be remarkable if this agreement were fortuitous. It seems that the minimum amount of genetic information normally required for replication of a DNA virus is much greater than that required for a RNA virus. This would be expected because of the greater structural complexity of the larger DNA viruses. It is uncertain how much of the DNA in these viruses is transmitted to daughter virus particles in the form of a single molecule. The experiments of Levinthal (1956) and of Stent, Sato \& Jerne (1959) suggest that about $40-60 \%$ of the DNA of T-even phages is transferred to progeny virus particles in the form of molecules containing not less than $15 \%$ of the amount of DNA/phage particle (i.e. having a molecular weight of 20 millions).

Cheng (1959) suggested that there is a widespread mechanism which limits chain lengths of DNA molecules to give basic molecular weights of about 4 millions. However, when the DNA of T-even phages is carefully prepared (Davison, 1959) it has a high sedimentation coefficient $\left(S_{20 \mathrm{w}}=60\right.$, corresponding to a molecular weight approaching 100 millions). High molecular-weight DNA is readily broken down to smaller units by turbulence and high shear gradients such as those produced by pipetting solutions. Hence reports of low molecular weights of extracted DNA preparations are open to doubt on technical grounds.

There are two known exceptions to the rule that DNA viruses have nucleic acid contents of molecular weight 60 to 260 millions. One is the small phage $\phi \mathrm{X174}$, which has a single-stranded DNA and a nucleic acid content of the same order as that in the RNA viruses (about 2 millions). The other is the rabbit papilloma virus, which probably has a double-stranded DNA content of the order of 7 millions. The same is probably true of the structurally related, but not identical, polyoma virus which produces multiple tumours when inoculated into mice and hamsters. The successful initiation of infection with DNA extracts of all of these three viruses has been reported (Di Mayorca, Eddy, Stewart, Hunter, Friend \& Bendich, 1959; Sekiguchi, Taketo \& Takagi, 1960; Ito, 1960). The infectivity was abolished by deoxyribonuclease but not by ribonuclease; neither enzyme has any effect on intact virus. The preparation of infective DNA from these viruses is evidently not due to a single-stranded configuration, since papilloma virus DNA is double stranded. However, for technical reasons mentioned above, the preparation of intact DNA molecules of very high molecular weight such as occur in most viruses is likely to be much more difficult than the preparation of intact molecules of molecular weight 2-7 millions.

The origin of DNA viruses has been discussed elsewhere (Luria, 1953). There is enough evidence to consider seriously the view that they may be pieces of chromosomal DNA that have become differentiated so that cell-to-cell transfer occurs 
efficiently. The location of prophage on the host chromosome, and phenomena such as transduction and lysogenic conversion, are powerful arguments in support of this view in the case of bacteriophages. No strictly analogous phenomena are known for the DNA viruses of insects and vertebrates, but other points of resemblance with phages suggest that they may have had similar origins. The fact that some DNA viruses, such as vaccinia and Tipula iridescent virus, multiply in the cytoplasm of infected cells is not a decisive argument against this view. Enzymes required for DNA synthesis are present in cytoplasm (Kornberg, 1960), and the site in the cell where DNA replication takes place may depend simply on the location of the template or 'primer'.

If it be accepted that members of the rickettsia and psittacosis-lymphogranuloma groups have evolved from bacterium-like precursors, the question arises whether the true viruses might have arisen by further modification of organisms of this type. The change would have involved the loss (simultaneously or successively) of either DNA or RNA, of mucopeptide cell walls and penicillin sensitivity, of a tetracyclinesensitive protein synthetic pathway and sulphonamide-sensitive metabolism. The mode of reproduction would have had to change from binary fission to one in which nucleic acid and virus protein are independently synthesized and then reassembled (Schäfer, 1959; Cohen, 1957). A radical series of metabolic changes of this type might conceivably have occurred, but it seems simpler to regard the DNA and RNA viruses as modified cell constituents.

\section{Comment on $R N A$ viruses}

There has already been much discussion of the fact that all RNA viruses so far analysed have nucleic acid molecular weights of the order of 2 million. Infectious RNA extracted from tobacco mosaic and foot-and-mouth disease viruses have molecular weights of the same order (Gierer, 1960; Ströhmaier \& Mussgay, 1959). In other words, all the RNA in these viruses appears to be present in a single polynucleotide chain containing some 6000 nucleotides. A single break in the polynucleotide chain produced by ribonuclease digestion, or modification of more than one base by nitrous acid treatment, is sufficient to abolish infectivity (Gierer, 1960). Hence the polynucleotide chain has to be transmitted intact to the recipient cell in order to reproduce itself and to initiate the synthesis of a virus-specific protein coat.

Microsomes from animal and plant tissues and ribosomes from bacteria also have RNA contents corresponding to about 2 millions (Palade \& Siekevitz, 1956; Ts'o, Bonner \& Vinograd, 1958; Gierer, 1958; Tissières \& Watson, 1958). This coincidence has raised the question whether RNA viruses could have originated from cellular particles containing RNA. Available evidence seems rather against this view. The suggestion (Crick \& Watson, 1956) that ribosomal particles might have the same structure as spherical viruses, with protein subunits regularly arranged around an RNA core, has not been borne out by recent observations on ribosomes. Furthermore, current work suggests that the structural RNA of ribosomes is not directly concerned with protein synthesis, but that a short-lived RNA intermediate serves as the 'messenger' carrying genetic information from nuclear DNA to protein (Brenner, Jacob \& Meselson, 1961; Gros et al. 1961).

There is presumptive evidence that RNA can also carry information from one 


\section{Nucleic acid contents of viruses}

cell to another. Extracts containing RNA added to bacteria have been reported to initiate the synthesis of enzymes not present in the recipient cells (Kramer \& Straub, 1956). Preparations containing RNA added to embryonic cells are stated by Niu (1958) to bring about specific differentiation. These effects are lasting, which suggests that the RNA may be replicated in the cells rather than being a short-lived messenger. It is but a small further step to a virus RNA molecule that is self-perpetuating and capable of redirecting the protein synthetic mechanisms of recipient cells to form specific products. These, in turn, might aggregate to coat the RNA and protect it from ribonuclease and other degradative agents. Transfer of RNA from cell to cell, normally a chance event with a low probability of influencing the recipient cell, might have been 'streamlined' by natural selection so that in viruses it has become a devastatingly efficient process. The reason why a minimum RNA molecular weight of 1 to 2 millions is apparently required for this process is not clear. This is considerably more than the amount of RNA which would be required for specifying the amino-acid sequences of protein subunits on current coding hypotheses. Hence it would seem that virus RNA has to subserve other functions during the course of self-replication. Evidence is accumulating that some tobacco mosaic mutants have normal protein subunits (Wittmann, 1960), which would be in accordance with this interpretation.

We are indebted to Dr K. M. Smith, Dr J. W. Beard, Dr H. G. Pereira and Dr C. Kaplan for samples of various viruses, and to Dr R. C. Valentine for electron micrographic examinations and spray counts of preparations.

\section{REFERENCES}

Allison, A. C. \& Armstrong, J. A. (1960). Abnormal distribution of nucleic acids in tissue culture cells infected with polyoma virus. Brit. J. Cancer, 14, 313.

Aluison, A. C. \& Perkins, H. R. (1960). The presence of cell walls like those of bacteria in rickettsiae. Nature, Lond. 188, 796.

Amres, C. R. (1938). The production of homogeneous suspensions of vaccinia elementary bodies and the histology of the associated skin lesions. J. Path. Bact. 47, 205.

Armstrong, J. A. \& Hopper, P. K. (1959). Fluorescence and phase-contrast microscopy of human cell cultures infected with adenovirus. Exp. Cell Res. 16, 584.

Armstrong, J. A. \& Niven, J. S. F. (1957). Histochemical observations on cellular and virus nucleic acids. Nature, Lond. 180, 1335.

Bawden, F. C. \& Pirie, N. W. (1945). Further studies on the purification and properties of a virus causing tobacco necrosis. Brit. J. exp. Path. 26, 277.

Belozersky, A. N. \& Spirin, A. S. (1958). A correlation between the compositions of deoxyribonucleic and ribonucleic acids. Nature, Lond. 182, 111.

Bergold, G. H. (1947). Die Isolierung des Polyedervirus und die Natur der Polyeder. Z. Naturf. $2 b, 122$.

Bergold, G. H. (1958). Viruses of insects. In Handbuch der Virusforschung, 4, 60. Ed. C. Hollauer and K. F. Meyer. Vienna: Springer.

Bonar, R. A. \& Beard, J. W. (1959). Virus of avian myeloblastosis. XII. Chemical constitution. J. nat. Cancer Inst. 23, 183.

Bradish, C. J., Henderson, W. M. \& Kirkham, J. B. (1960). Concentration and electron microscopy of the characteristic particle of foot-and-mouth disease. J. gen. Microbiol. 22, 379.

Brenner, S., JAcob, F. \& Meselson, M. (1961). An unstable intermediate carrying information from genes to ribosomes for protein synthesis. Nature, Lond. 190, 576. 
Burton, K. (1956). A study of the conditions and mechanism of the diphenyl-alanine reaction for the colorimetric estimation of deoxyribonucleic acid. Biochem. J. 62, 315.

Cheng, P. (1959). On the similarity of chain lengths of nucleic acids. Proc. nat. Acad. Sci., Wash. 45, 1557.

Conen, S. S. (1957). The biosynthesis of nucleic acids in some microbial systems. In The Chemical Basis of Heredity, p. 651. Ed. W. D. McElroy \& B. Glass. Baltimore: Johns Hopkins Press.

Cohen, S. S. \& Chargaff, E. (1944). Studies on the composition of Rickettsia prowazeki. J. biol. Chem. 154, 691.

Corin, Z. A., Hain, F. E., Cegalowski, W. \& Bozeman, F. M. (1958). Unstable nucleic acids of Rickettsia mooseri. Science, 127, 282.

Crick, F. H. C. \& Watson, J. D. (1956). Virus structure: general principles. In Ciba Foundation Symposium on The Nature of Viruses, p. 5. Ed. J. E. W. Wolstenholme \& F. P. Miller. London: Churchill.

Crocker, T. T. (1952). Estimates of particle number, lethal effect and chemical properties of virus meningopneumonitis. Fed. Proc. 11, 464.

Crocker, T. T. \& Williams, R. C. (1955). Electron microscopic morphology of frozendried particles of meningopneumonitis virus. Proc. Soc. exp. Biol., N.Y. 88, 378.

Davison, P. F. (1959). The effect of hydrodynamic shear on the deoxyribonucleic acid from T2 and T4 bacteriophages. Proc. nat. Acad. Sci., Wash. 45, 1560.

Dawson, I. M. \& McFarlane, A. S. (1948). Structure of an animal virus. Nature, Lond. $161,464$.

De Fremery, D. \& Knight, C. A. (1955). A chemical comparison of three strains of tomato bushy stunt virus. J. biol. Chem. 214, 559 .

Di Mayorca, G. A., Eddy, B. E., Stewart, S., Hunter, W. S., Friend, C. \& Bendich, A. (1959). Isolation of infectious deoxyribonucleic acid from $S E$ polyoma-infected tissue cultures. Proc. nat. Acad. Sci., Wash. 45, 1805.

Epstern, M. A., Holt, S. J. \& Powell, A. K. (1960). The fine structure and composition of type 5 adenovirus; an integrated electron microseopical and cytochemical study. Brit. J. exp. Path. 41, 567.

Faulkner, P., Martin, E. M., Sved, S. \& Work, T. S. (1960). Crystallization of purified mouse encephalomyocarditis particles. Nature, Lond. 186, 908.

Frisch-Niggemeyer, W. (1956). Absolute amount of ribonucleic acid in viruses. Nature, Lond. 178, 307.

Gessi.er, A., Bender, C. E. \& Parkinson, M. C. (1956). A new and rapid method for isolating viruses by selective fluorocarbon deproteinization. Trans. N.Y. Acad. Sci. 18, 701.

Grerer, A. (1958). Vergleichende Untersuchungen an hochmolekularer Ribosenucleinsäure. Z. Naturf. 136, 788.

Grerer, A. (1960). Ribonucleic acid as genetic material of viruses. Symp. Soc. gen. Microbiol. 10, 248.

Gros, F., Hiatt, H., Gilbert, W., Kurland, C. G., Risebrough, R. W. \& Watson, J. D. (1961). Unstable ribonucleic acid revealed by pulse labelling of Escherichia coli. Nature, Lond. 190, 581.

Harrison, B. D. \& Nixon, H. L. (1959). Separation and properties of particles of tobacco rattle virus with different lengths. J. gen. Microbiol. $21,569$.

Hart, P. D'A. \& Rees, R. J. W. (1960). Effect of macrocyclon in acute and chronic pulmonary tuberculosis infection in mice as shown by viable and total bacterial counts. Brit. J. exp. Path. 41, 414.

Hoagland, C. L., Lavin, G. I., Smadel, J. E. \& Rivers, T. M. (1940). Constituents of elementary bodies of vaccinia. II. Properties of nucleic acid obtained from vaccine virus. J. exp. Med. 62, 139.

Hopkins, G. R. \& Sinsheimer, R. L. (1959). Visible and ultraviolet light scattering by tobacco mosaic virus nucleic acid. Biochim. biophys. Acta, 17, 476.

Hoyer, B. A., Bolton, E. T., Ormsbee, R. A., Le Bouvier, G., Ritter, D. B. \& Larson, C. L. (1958). Mammalian viruses and rickettsiae. Science, 127, 859. 


\section{Nucleic acid contents of viruses}

ITo, Y. (1960). A tumor-producing factor extracted by phenol from papillomatous tissue (Shope) of cottontail rabbits. Virology, 12, 596.

KNIGHT, C. A. (1954). The chemical constitution of viruses. Advanc. Virus Res. 2, 153.

Kornberg, A. (1960). Biologic synthesis of deoxyribonucleic acid. Science, 131, 1508.

Kramer, M. \& Straub, F. B. (1956). Role of specific nucleic acid in induced enzyme synthesis. Biochim. biophys. Acta, 21, 401.

Krieg, A. (1956). Über die Nucleinsäure der Polyederviren. Naturwissenschaften, 43, 537.

Levinthal, C. (1956). The mechanism of DNA duplication and genetic recombination in phage. Proc. nat. Acad. Sci., Wash. 42, 394.

Loeb, 'T. \& Zinder, N. D. (1961). A bacteriophage containing RNA. Proc. nat. Acad. Sci., Wash. 47, 282.

Lowry, O. H., Rosebrough, N. J., Farr, A. L. \& Randald, R. J. (1951). Protein measurement with the Folin phenol reagent. J. biol. Chem. 193, 265.

Lunan, K. D. \& Sinsheimer, R. L. (1956). A study of the nucleic acid of bacteriophage T7. Virology, 2, 455.

LuriA, S. E. (1953). General Virology. New York: John Wiley.

Lwoff, A. (1957). The concept of virus. J. gen. Microbiol. 17, 239.

MarkhaM, R. \& Smith, K. M. (1951). Chromatographic studies of nucleic acids. 4. The nucleic acid of the turnip yellow mosaic virus, including a note on the nucleic acid of the tomato bushy stunt virus. Biochem. J. 49, 401 .

Marmur, J. \& Doty, P. (1958). Heterogeneity in deoxyribonucleic acids. Nature, Lond. $183,1427$.

Miller, G. L. \& Price, W. C. (1946). Physical and chemical studies on southern bean mosaic virus. Arch. Biochem. Biophys. 10, 467.

Morawitz, H. J. \& Cleverden, R. C. (1959). An extreme example of the coding problem, avian PPLO 5969. Biochim. biophys. Acta, 34, 578.

Morgan, C., Howe, C., Rose, H. M. \& Moore, D. H. (1956). Structure and development of viruses observed in the electron microscope. iv. Viruses of the R1-APC group. J. biophys. biochem. Cytol. 2, 351.

Mouldir, J. W. \& Werss, E. (1951). Purification and properties of the agent of feline pneumonitis. J. infect. Dis. 88, 56.

Niv, M. C. (1958). Thymus ribonucleic acid and embryonic differentiation. Proc. nat. Acad. Sci., Wash. 44, 1264.

Palade, G. \& Srexevitz, P. (1956). Liver microsomes. An integrated morphological and biochemical study. J. biophys. biochem. Cytol. $2,171$.

PARK, J. T. (1958). Inhibition of cell wall synthesis in Staphylococcus aureus by chemicals which cause accumulation of cell wall precursors. Biochem. J. 70, 2 P.

PaUl, H. L. (1959). Die Bestimmung des Nucleinsäuregehaltes pflantzlicher Viren mit Hilfe einer spektrophotometrischen Methode. Z. Naturf. 14b, 427.

Pereira, H. G. \& Valentine, R. C. (1958). Infectivity titrations and particle counts of adenovirus type 5. J. gen. Microbiol. 19, 178.

Pollard, M., Starr, T. J., Moore, R. W. \& Tanami, Y. (1960). Cytochemical changes in human amnion cells infected with psittacosis virus. Nature, Lond. 188, 770.

Roberts, R. B., Cowie, D. B., Abelson, P. H., Bolton, E. T. \& Britten, R. J. (1955). Studies of biosynthesis in Escherichia coli. Publ. Carneg. Instn, p. 521.

Rogers, H. J. \& Perkins, H. R. (1959). Cell-wall mucopeptides of Staphylococcus aureus and Micrococcus lysodeiktikus. Nature, Lond. 184, 520.

Ross, M. R. \& Gogolak, F. M. (1957). Antigenic structure of psittacosis and feline pneumonitis viruses. II. Chemical nature of the soluble antigens. Virology, 3, 365.

Schaechter, M., Bozeman, F. M. \& Smadel, J. (1957). Study on the growth of Rickettsiae: II. Morphologic observations of living rickettsiae in tissue culture cells. Virology, $3,160$.

SCHÄFER, W. (1959). Some observations concerning the reproduction of RNA-containing animal viruses. Symp. Soc. gen. Microbiol. 9, 61.

Sekiguchi, M., Taketo, A. \& Takagi, Y. (1960). An infective deoxyribonucleic acid from bacteriophage $\phi$ X174. Biochim. biophys. Acta, 45, 199. 
Sinshermer, R. L. (1959). A single-stranded deoxyribonucleic acid from bacteriophage $\phi$ X174. J. mol. Biol. $1,45$.

Smadel, J. E., Rivers, T. M. \& Prckels, E. G. (1939). Estimation of the purity and properties of elementary bodies of vaccinia. J. exp. Med. 70, 379.

Smith, J. D. \& WyatT, G. R. (1951). The composition of some microbial deoxypentose nucleic acids. Biochem. J. 49, 144.

Smith, J. D. \& Stoker, M. G. P. (1951). The nucleic acids of Rickettsia burneti. Brit. J. exp. Path. 32, 433.

Steiniaus, E. A. (1946). Insect Microbiology. Ithaca: Comstock.

Stent, G. S. (1958). Mating in the reproduction of bacterial viruses. Advanc. Virus Res. $5,95$.

Stent, G. S. \& Funrst, C. R. (1955). Inactivation of bacteriophages by decay of incorporated radioactive phosphorus. J. gen. Physiol. 38, 441.

Stent, G. S., Sato, G. H. \& Jerne, N. K. (1959). Dispersal of the parental nucleic acid of bacteriophage $\mathbf{T} 4$ among its progeny. J. mol. Biol. 1, 134 .

Strörmaicr, K. \& Mussgay, M. (1959). Density-gradient centrifugation with infectious ribonucleic acid of foot-and-mouth disease virus. Science, 130, 217.

Taylor, A. R., Beard, D., Sharp, D. G. \& Beard, J. W. (1942). Nucleic acid of rabbit papilloma virus protein. J. infect. Dis. 71, 110.

Tissiènes, A. \& Watson, J. D. (1958). Ribonucleoprotein particles from Escherichia coli. Nature, Lond. 182, 778.

Ts'o, P. O. P., Bonner, J. \& Vinograd, J. (1958). Structure and properties of microsomal nucleoprotein particles from pea seedlings. Biochim. biophys. Acta, 30, 570.

Valentine, R. C. (1959). Quantitative electron staining of virus particles. J. R. micr. Soc. $78,26$.

Watson, J. D. \& Crick, F. H. C. (1953). The structure of DNA. Cold Spr. Harb. Symp. quant. Biol. 18, 123.

Watson, J. D.\& Littlefield, J. W.(1960). Some properties of DNA from Shope papilloma virus. J. mol. Biol. 2, 161.

WEBB, J. M. (1956). A sensitive method for the determination of ribonucleic acid in tissues and microorganisms. J. biol. Chem. 221, 635.

Wenner, H. A. (1958). Psittacosis-lymphogranuloma group of viruses. Advanc. Virus Res. 5, 39.

Williams, R. C. \& Backus, R. C. (1949). Macromolecular weights determined by direct particle counting. 1. The weight of the bushy stunt virus particle. J. Amer. chem. Soc. $71,4052$.

Williams, R. C., KaSs, S. J. \& KNIGht, C. A. (1960). Structure of Shope papilloma virus particles. Virology, 12, 48.

Williams, R. C. \& Smith, K. M. (1957). A crystallizable insect virus. Nature, Lond. 179, 119.

Wittmann, H. G. (1960). Comparison of the tryptic peptides of chemically induced and spontaneous mutants of tobacco mosaic virus. Virology, 12, 609.

Wyatt, G. P. \& Cohen, S. S. (1952). Nucleic acids of Rickettsiae. Nalure, Lond. 170, 846.

Zahler, S. A. \& Moulder, J. W. (1953). The incorporation of radioactive phosphate into feline pneumonitis virus in the chick embryo yolk sac. J. infect. Dis. 93, 159. 